\title{
Desafios em torno do sangue na produção de corações artificiais
}

Marisol Marini ${ }^{1}$

Universidade de Campinas

Resumo: A manutenção do sangue em circulação é vital para os corpos. Quando se encontra comprometida, como no caso da insuficiência cardíaca avançada, condição patológica associada a um alto índice de mortalidade na atualidade, é necessária a substituição do órgão doente, ou o auxílio de dispositivos de assistência circulatória, conhecidos como corações artificiais. Um dos maiores desafios no desenvolvimento de tecnologias auxiliares, que promovem a circulação mecânica, está associado à perfusão e distribuição do sangue pelo corpo de maneira harmônica, de modo a preservar as células do sangue. Nesse sentido, algumas das questões que se colocam no atual cenário de desenvolvimento de corações artificiais são: como substituir "artificialmente" a função do bombeamento cardíaco de maneira eficaz sem atuar como um "liquidificador celular"? Como performar mecanicamente a perfusão das células mimetizando da melhor forma a fisiologia nativa/ideal? São os desafios em torno de uma boa circulação mecânica - o que se relaciona aos modos de compreensão do sangue e do corpo como um sistema, uma máquina - que o artigo abordará. São os riscos associados à extrapolação da fronteira da pele, tão fictícia e igualmente real, e os desafios de manter a circulação (auto)contida, nas situações em que o sangue escapa ao disciplinamento, que serão aqui explorados. Tais problemáticas serão investigadas à luz de teorias e abordagens interessadas na materialidade e na centralidade das práticas sociomateriais, laboratoriais e clínicas por meio das quais tais dispositivos/corpos emergem.

Palavras-chave: sangue; corpo; antropologia da tecnociência; coração artificial; teorias feministas e novos materialismos.

${ }^{1}$ Doutora em Antropologia Social pela USP. Atualmente desenvolve pesquisa de pós-doutorado na Unicamp. Integra os grupos de pesquisa: NUMAS - Núcleo de Estudos dos Marcadores Sociais da Diferença, LAPOD - Laboratório de Estudos Pós-Disciplinares e GEICT - Grupo de Estudos Interdisciplinares em Ciência e Tecnologia. 


\title{
Desafíos relacionados con la sangre en la producción de corazones artificiales
}

\begin{abstract}
Resumen: Mantener la sangre en circulación es vital para los cuerpos. Sin embargo, existen situaciones en las que la circulación se ve comprometida, como es el caso de la insuficiencia cardíaca avanzada, una condición patológica asociada a una alta tasa de mortalidad. En este caso, es necesario reemplazar el órgano enfermo o utilizar dispositivos de asistencia circulatoria, conocidos como corazones artificiales. Uno de los mayores desafíos en el desarrollo de tecnologías auxiliares, que promueven la circulación mecánica, está asociado con la perfusión y distribución de la sangre por todo el organismo de manera armónica, cuyo objetivo es la preservación de las células sanguíneas. En este sentido, algunas de las preguntas que surgen en el escenario actual de desarrollo de corazones artificiales son: ¿Cómo reemplazar "artificialmente" la función de bombeo cardíaco de manera efectiva sin actuar como un "licuadora de células"? ¿Cómo realizar mecánicamente la perfusión de células, imitando mejor la fisiología nativa/ideal? Son entonces los desafíos que se presentan para obtener una buena circulación mecánica, que se relaciona con las formas de entender la sangre y el cuerpo como un sistema, y /o como una máquina, los que abordará ese artículo. De igual manera, los riesgos asociados a la extrapolación del borde cutáneo, tan ficticio e igualmente real, y los desafíos de mantener la circulación (auto)contenida, en situaciones donde la sangre se escapa de las disciplinas, los que aquí serán explorados. Estos temas serán investigados a la luz de teorías y enfoques interesados en la materialidad y centralidad de las prácticas socio-materiales, de laboratorio y clínicas a través de las cuales emergen tales dispositivos/cuerpos.
\end{abstract}

Palabras clave: sangre; cuerpo; antropología tecnociencia; corazón artificial; teorías feministas y nuevos materialismos.

\section{Challenges around blood in the production of artificial hearts}

\begin{abstract}
Keeping blood circulating is vital for bodies. When circulation is compromised, as in the case of advanced heart failure, a pathological condition associated with a high mortality rate nowadays, it is necessary to replace the diseased organ, or add circulatory assistant devices, known as artificial hearts. One of the biggest challenges in the development of auxiliary technologies, which promote mechanical circulation, is associated with the perfusion and distribution of blood throughout the body in a harmonic way, in order to preserve blood cells. Some of the questions that arise in the current scenario of developing artificial hearts are: how effectively and artificially replace the function of cardiac pumping without acting as a "cell blender"? How to mechanically perform the perfusion of cells to better mimic the native/ideal physiology? It is the challenges about good mechanical blood distribution - which relates to ways of understanding blood and the body as a system, a machine - that the article will address. It is the risks associated with the extrapolation of the skin border, so fictitious and at the same time so real, and the challenges of maintaining the (self)contained circulation, in situations where blood escapes from disciplining, which will be explored here. Such problems will be investigated in the light of theories and approaches interested in the materiality and centrality of socio-material, laboratory and clinical practices through which such devices/bodies emerge.
\end{abstract}

Keywords: blood; body; technoscience anthropology; artificial heart; feminist theories and new materialisms. 
A pergunta que orienta o dossiề ${ }^{2}$, “o que carrega o sangue?”, na lógica do conhecimento fisiológico e anatômico que informa a produção de corações artificiais remete às suas propriedades químicas e físicas. Somente quando sua fluidez é estacionada em ferramentas que permitem um acesso microscópio ao fluido é que se ilumina sua "composição", suas partes, e o que elas carregam. Os mundos e seres se multiplicam. Há partículas diversas, que carregam outras e são carregadas. No desenvolvimento de dispositivos de assistência circulatória uma das principais questões a ser respondida é como impulsionar o sangue, como carregá-lo ou permitir que ele possa fluir, espalhando sua multiplicidade de existências 3 por um organismo delimitado pelas fronteiras da pele, constituindo um sistema semiaberto (ou semifechado).

É a propriedade mecânica da circulação do sangue, que tem o coração como centro e motor da dinâmica de distribuição, que se coloca como principal desafio. Se a movimentação mecânica do fluido não for bem executada pode acarretar relações indesejadas, parcerias perigosas, aglomerações que podem produzir impedimento da circulação, podendo provocar interrupções de fluxo e acidentes de grandes proporções, incluindo o risco de letalidade.

O corpo precisa ser alimentado elétrica, mecânica e quimicamente e os fluxos mantidos em movimento. Circulações e relações devem ser promovidas, enquanto outras evitadas. São os desafios em torno de uma boa circulação mecânica - o que se relaciona aos modos de compreensão do sangue e do corpo como um sistema, uma máquina - que o artigo abordará. São as dificuldades de substituir mecanicamente o trabalho do coração e do sangue, que ocupam os pesquisadores engajados na produção de tecnologias cardíacas, que serão aqui descritas, desdobradas e interpretadas. São os riscos associados à extrapolação da fronteira da pele, tão fictícia e igualmente real, e os desafios de manter a circulação (auto)contida, investigando situações em que o sangue escapa ao disciplinamento, que serão aqui explorados.

Para abordar a temática do sangue no âmbito do desenvolvimento de tecnologias médicas de assistência circulatória - objetos/sujeitos da pesquisa de doutorado realizada por mim junto a uma rede de artefatos, dispositivos, seres e pesquisadores - optei por trazer um caleidoscópio de cenas e situações etnográficas nas quais o sangue emerge como um importante actante, materializando-se numa ecologia de práticas e relações que serão aqui descritas. O intuito é investigá-las à luz de teorias e abordagens interessadas na materialidade e nas práticas.

\footnotetext{
${ }^{2}$ A presente reflexão é decorrente do paper apresentado no GT "O que carrega o sangue? Elaborações em torno do sangue e seus potenciais produtivos”, do qual resulta o dossiê. Agradeço às pessoas presentes naquela ocasião pelo diálogo, sobretudo à Juliana Caruso e Carolina Portela pela parceria e por todas as trocas e fluxos. Agradeço também aos dois ótimos pareceres que o artigo recebeu no processo de avaliação para a publicação, assim como a leitura cuidadosa da Joana Cabral de Oliveira, que motivaram ótimas reflexões.

3 Joana Cabral de Oliveira me provocou a pensar se a multiplicidade do sangue que corre dentro das veias é constitutiva, ou se há uma multiplicidade emergente, mediante um translado em procedimentos laboratoriais e médicos. Ou seja, o sangue nas veias, o sangue no microscópio, o sangue amostra, o sangue transplantado de seu sistema nativo etc. Sugiro que seja possível distinguir dois aspectos de multiplicidade: por um lado o sangue que aos nossos olhos é uma substância amorfa, indefinida, ao ser submetido à visualização microscópica demonstra-se composto por seres e "elementos" diversos. Por outro lado, nas práticas laboratoriais, cirúrgicas e médicas que serão aqui descritas, uma multiplicidade ontológica emerge por meio de procedimentos nos quais o sangue pode ser amostra, fluido, densidade, viscosidade etc., atuando e traduzindo-se em ontologias distintas.
} 
Emprego os termos sujeitos e actante (atuante) como uma estratégia para escapar da ideia de ator comumente associada exclusivamente a humanos, a menos que ator seja tomado no sentido atribuído por Latour, para quem: "ao invés de começar com entidades que já compõem o mundo, os estudos científicos enfatizam a natureza complexa e controvertida do que seja, para um ator, chegar à existência. O segredo é definir o ator com base naquilo que ele faz" (LATOUR, 2001: 346). O que está em jogo é desafiar as compreensões mais básicas que sustentaram o mundo moderno, incluindo o senso normativo sobre o humano e crenças sobre agência (puramente) humana (COOLE e FROST, 2010).

Ao abordar a fabricação de fatos científicos na produção mútua de fermentos e do cientista (Pasteur), por exemplo, Latour (2011) procura demonstrar que a única maneira de definir um ator é por intermédio de sua atuação, e da indagação a respeito de como a atuação transformou outros actantes. Nesse sentido, só é possível falar em ator se considerarmos que não apenas humanos transportam informação, (inter)agem e produzem efeitos. Ou, para escapar à racionalidade que a troca de informações pode sugerir, inspirada nas formulações de MerleauPonty, sugiro que tem vida tudo aquilo que exerce sua potência de inventar o visível, o que remete a uma dimensão de composição, de uma inclinação ao compartilhamento, de modo que podemos considerar que produz ação tudo aquilo que se inclina à existência compartilhada, à "interanimalidade" (MERLEAUPONTY, 2000). É conveniente, no entanto, abandonar a metáfora visual proposta por Merleau-Ponty se precisamos dar conta de existências múltiplas, não-humanas e pós-humanas. ${ }^{4}$ É um imperativo para a reconfiguração das relações e para a compreensão da matéria e as condições resultantes de sua atuação no século XXI, momento em que manobras sem precedentes são reservadas à matéria e à vida (COOLE e FROST, 2010). É preciso nos fazer sensíveis à capacidade de se relacionar dos não-humanos. É necessária disposição para perceber e compreender suas atuações, aprender a observar as relações entre seres e entes diversos, que não podem de saída serem aprisionados nos polos da natureza ou da cultura.

Interessa-me pensar aqui a concepção de atividade distribuída, defendendo a redistribuição da capacidade de (inter)ação entre humanos e não-humanos. Se no experimento "Pasteur age para que a levedura aja sozinha" (LATOUR, 2001: 151), é porque o foco da atenção está na atividade laboratorial disparada pelo cientista. Para Latour, "um experimento é um ato realizado pelo cientista para que o não-humano apareça por si mesmo". E quanto mais o cientista desenvolve o procedimento, quanto mais Pasteur trabalha, sugere Latour, mais independente se torna a substância que ele manipula.

É claro que a potência de ação que tem como ponto de partida a atuação de cientistas se deve à observação de atividades laboratoriais entendidas como dis-

\footnotetext{
4 É preciso também questionar a compreensão de certa preeminência da visão entre os sentidos humanos. Ingold (20o8) destaca que para indagações próprias de uma ciência positivista, a visão pode ser tomada como um sentido superior. Em contraste com a audição, que personifica, à visão é atribuída capacidade de objetificar. Entretanto, o caminho visual para a verdade objetiva é pavimentado de ilusões, como ele sugere. Além disso, ao tentar lidar com a questão de como as pessoas percebem o mundo à sua volta Ingold problematiza as concepções de Descartes sobre os sentidos, vistos por ele como uma faculdade puramente cognitiva. Para Descartes o ato da percepção se divide em dois estágios, o primeiro que leva de um encontro físico com um objeto a um padrão de estímulo nervoso no cérebro e o segundo que leva desses impulsos nervosos a uma consciência mental do objeto na linha de visão do perceptor. Assim, a essência da visão residiria não no funcionamento dos olhos, mas antes nas operações da mente sobre o que é levado a ela pelos sentidos. No entanto, para Ingold, o processo de visão não consiste em uma radiação incidente que termina como uma imagem mental, mas sim em um processo interminável de engajamento exploratório dialógico entre o perceptor e seu ambiente. Ingold considera que deveríamos deixar de pensar na percepção como a atividade computacional de uma mente dentro de um corpo e vê-la como uma atividade exploradora do organismo dentro de seu ambiente, superando, desse modo, uma lógica que opõe representação mental à sensação corporal que, em sua opinião, reifica os sentidos como aspectos de uma natureza humana universal. Ao dissolver a fronteira entre o eu e o mundo, interior e exterior, Ingold pretende superar o dualismo cartesiano e dissolver o "grande divisor" entre sociedades ocidentais e não-ocidentais.
} 
paradas por humanos. Essas podem ser situações em que os não-humanos reagem às atuações humanas, às vezes de maneira inesperada e imprevista, impondo desafios aos pesquisadores que disponibilizam seus corpos e habilidades. Mas nem sempre há humanos participando das relações. Os não-humanos podem também exercer sua identidade, ainda que não permanecendo nela, como toda e qualquer existência, como sugere Merleau-Ponty (2000). Em sua elaboração, trata-se de uma exigência ontológica ultrapassar a oposição abstrata entre o "ser" e o "nada". Nesse sentido, "ser" não significa permanecer na identidade, mas criar e abrir espaço para sua própria "espessura" e "profundidade" (MARTINS, 2010)5. Desse modo, "ser" não é um atributo de humanos, que se caracterizam como um dos sujeitos com os quais é possível associar-se, mas não os únicos.

O protagonismo e atenção dada ao sangue é decorrente da abordagem teórico-metodológica que informou o desenvolvimento da pesquisa, interessada nas práticas e na materialidade emergente nas relações. Desse modo, o foco nas práticas por meio das quais os corpos emergem permitiu avançar na compreensão das relações instituídas na e para a produção de corações artificiais. Em linhas gerais, o intuito da pesquisa foi descrever e analisar os aspectos práticos, materiais, os eventos por meio dos quais as cardiopatias, os dispositivos mecânicos, as soluções para a insuficiência cardíaca e os corpos tornam-se parte do que é feito na prática laboratorial, cirúrgica e clínica. Atentar para as práticas por meio dais quais emergem os objetos/fenômenos, permite destacar que a ontologia não é dada na ordem das coisas, mas ontologias são trazidas à existência (Mol, 2002) e são sustentadas por práticas sociomateriais, de modo que a materialidade ocupa um aspecto central na análise.

Alio-me às teóricas que propõe um feminismo orientado por objetos. A partir de suas investigações a respeito de doenças cardíacas, por exemplo, Anne Pollock (2015) propôs a ideia de "heart feminism" buscando, além de colocar o coração em primeiro plano, ressaltar a inseparabilidade da matéria e dos significados. Inspirada pelas análises de Elizabeth Wilson sobre o intestino, Pollock recorre à sua imagem de que o sistema neurológico se estende muito além do cérebro, e uma evidência disso é que há neurônios fora dele. Partir do coração, para Pollock, implica considerar suas articulações, e não operar por redução. Seu domínio vai muito além do próprio órgão, se desdobrando para todo o sistema circulatório. $\mathrm{O}$ coração é crucialmente um ponto de passagem e sua função está profundamente integrada ao sistema vascular periférico e ao corpo de maneira geral, bem como ao ambiente. A relação entre o coração como um ponto de passagem essencial e a distribuição democrática do sangue pelo organismo estabelece uma comunicação e dá unidade ao corpo. A ideia de distribuição democrática foi sugerida por um interlocutor da pesquisa, um pesquisador da bioengenharia, que certa vez colocou a questão nesses termos para se referir à não especialização celular, ou seja, a mesma célula que oxigena os tecidos do dedo do pé, também o faz no cérebro. Tal hemocracia remete não apenas à oxigenação produzida pela circulação do sangue, ou seja, à distribuição igualitária do sangue pelo corpo, mas também à comunicação, que institui uma forma de parlamento das coisas (LATOUR, 1994).

O que pode oferecer uma análise centrada no coração e no sistema circulatório? Ao lado de outras teóricas, Pollock procura trazer o corpo biológico de forma

\footnotetext{
5 É preciso destacar que espessura e profundidade não correspondem a ideias sobre a matéria atribuídas a Descartes, como substância corpórea constituída de comprimento, largura e espessura; extensa, uniforme e inerte - modelos que forneceram a base para ideias modernas da natureza como quantificáveis, que estão presentes na geometria euclidiana e na física newtoniana (COOLE e FROST, 2010). Não se trata desse modelo em que os objetos são discretos, se movem apenas no encontro com agentes ou forças externas, numa lógica linear de causa e efeito. Mais do que possuir espessura e profundidade, o que está em questão é a atuação, a (inter)ação, a habilidade de criar e ocupar espaço.
} 
produtiva ao escopo da análise feminista. A metáfora de uma espécie de atividade passiva do coração proposta por Pollock, ou seja, a atuação do órgão como sua receptividade, como sua capacidade de se abrir, de abrir espaço para que a impulsão do sangue ocorra, se articula à proposta de um feminismo centrado no coração, como uma estratégia de resistência à redução do humano a um sujeito cerebral, um contraponto a determinada neurociência e outros saberes que buscam no cérebro explicações simplistas para o que/quem somos. Algo semelhante se passa na argumentação de Jenny Slatman (MARINI, 2018), em sua sugestão de pensar uma filosofia do corpo, cujo intuito é problematizar e confrontar a proposição de uma filosofia da mente.

Além do enfrentamento ao reducionismo cerebral/mental, à dicotomia entre corpo e mente, e os distintos dualismos ${ }^{6}$ sustentados na e pela modernidade, a atenção à materialidade intenta recolocar o corpo nas cosmologias modernas. Enquanto há quem anuncie seu fim7 ou obsolescência, apoio-me nas teóricas feministas interessadas na materialidade e em pensadoras associadas à fenomenologia, para reivindicar a dignidade do corpo (Serres, 2004). Nesse sentido, sugiro que compreender o desenvolvimento de uma tecnologia cardíaca e as transformações promovidas no funcionamento do coração e do sistema circulatório permite outras articulações do sentido do humano.

À abordagem do feminismo orientado por objetos (POLLOCK, 2015), à performatividade pós-humanista (BARAD, 2003), à semiótica material (LAW, 2015), aos novos materialismos (COOLE e FROST, 2010) articula-se a perspectiva da praxiografia (MOL, 2002) e da virada para a prática nos Estudos Sociais de Ciência e Tecnologia, como, por exemplo, os desenvolvimentos da filósofa holandesa Annemarie Mol. Em sua proposta de filosofia empírica, Mol (2002) propõe colocar a prática em primeiro plano, descrevendo os processos por meio dos quais os objetos são feitos.

Iluminar os processos de emergência de novos corpos, de tecnologias e seu caráter processual, no entanto, não implica considerar que a materialidade seja uma ilusão, ou que os enredamentos sejam puro fluxo e devir. Descrever os processos por meio dos quais os dispositivos emergem possibilita justamente dar corpo às práticas, reconhecer os atores/actantes e as relações por eles instituídas, assim como observar os efeitos reais e duradouros que os arranjos heterogêneos podem produzir.

Os atores não-humanos serão devidamente qualificados e a categorização demasiada genérica até agora dará lugar a corpos e sujeitos específicos a seguir. A centralidade das práticas e da materialidade envolvida no engajamento entre pesquisadores, artefatos, tecnologias experimentais, e uma gama de atores nos levará a cenas diversas nas quais o sangue ganha protagonismo, na medida em que transforma as relações, coloca desafios ao desenvolvimento dos dispositivos. Além do caleidoscópio de cenas etnográficas, para iluminar os muitos mundos

\footnotetext{
6 Donna Haraway (2000), a partir do ciborgue procura problematizar os diversos dualismos, como as dicotomias entre animal e humano, organismo e máquina, público e privado, natureza e cultura, homens e mulheres, primitivo e civilizado, que, em sua opinião, estariam sendo "canibalizados" ou "tecnodigeridos" (nos termos de Zoe Sofia Sofoulis, citada por Haraway). A ideia de ciborgue é um importante conceito que nos permite escapar de divisões ontológicas precipitadas. 7 Emily Martin destaca que o foco das análises no corpo pode ser explicado pelo fenômeno já evidenciado por Lévi-Strauss, em Tristes Tópicos, a respeito do interesse na academia por objetos/sujeitos em vias de desaparecer. Nesse sentido, ela se pergunta se uma das razões para o interesse em estudar o corpo não seria o diagnóstico de que vivemos mudanças fundamentais no modo como organizamos e experimentamos os corpos: "Some have claimed that the body as a bounded entity is in fact ending under the impact of commodification, fragmentation, and the proliferation of images of body parts" (MARTIN, 1992). Em seu diagnóstico vivemos o fim de um corpo e o início de um novo, por isso seu interesse é investigar mudanças dramáticas e a transição de corpos adequados e concebidos nos termos da era Fordista de produção de massa - corpos disciplinados e organizados para a eficiência - para uma era de acumulação flexível, de um corpo que colapsa o espaço e o tempo, cujas respostas tornam-se cada vez mais flexíveis.
} 
aqui prenunciados recorrerei a conteúdos diversos, aproximações inusitadas e até fantasiosas.

\section{Uma pequena arqueologia do movimento}

O filo cnidária agrupa organismos aquáticos, multicelulares, com estruturas simples, caracterizado pela presença de uma estrutura celular conhecida como cnida. Assim como os fungos, os cnidários causaram controvérsias taxonômicas, ora entendidos como animais, ora como plantas. Entre os seus principais representantes estão as águas-vivas, as caravelas, as anêmonas-do-mar e os corais. São espécies que possuem células epiteliais com fibras musculares cujas contrações possibilitam que os animais se movam. A mobilidade é uma habilidade para a qual são necessários nervos e músculos. Uma pesquisa atual (STEINMETZ et al., 2012) destacou a importância dos cnidários no quadro evolucionário e ecológico em diversos campos das ciências da vida. Trata-se de uma investigação complexa, que aponta para a possibilidade de o surgimento de células musculares ser anterior à sua especialização. O estudo identificou um conjunto de proteínas contráteis que pré-datavam a adaptação das células e tecidos musculares. Portanto, embora reconheça as contribuições dos cnidários no quadro evolutivo, o estudo evidencia que suas inovações podem estar relacionadas a desdobramentos anteriores, uma vez que proteínas (proto) musculares foram encontradas em outros organismos.

O ponto que nos interessa é a formação de uma terceira camada de tecido, uma camada muscular, que permitiu aos cnidários movimentar-se, o que lhes deu uma vantagem evolutiva, no idioma evolucionista. Para os animais nas mesmas condições que os cnidários, porém incapazes de se movimentar, só restava obter alimento a partir da água marinha que os atravessava. A mobilidade, além de facilitar a obtenção de alimentos, oferece maiores possibilidades de fugir de presas, lutar com elas, explorar novos lugares. Nessa narrativa evolucionista que busca traçar um pioneirismo, ao desenvolver músculos, os Cnidários teriam mudado suas vidas e o mundo. De acordo com cientistas (STEINMETZ et al., 2012; LECLÈRE et al.,2016), eles marcaram uma virada no comportamento animal. Há mais de 500 milhões de anos, os cnidários, provavelmente por processos de bricolagem, adaptaram células, produzindo novas propriedades e habilidades. Além de uma boca conectada a um sistema digestivo (chamada de cavidade gastrovascular), os corpos dos cnidários se movimentaram. Mas a que se refere essa ideia de invenção do movimento pelos cnidários? De que movimento se trata? Será possível aproximá-lo de um movimento "ativo", do tipo questionado por Pollock 8 ? É preciso considerar que há uma inovação em seus corpos: seus músculos. E para controlar os músculos, uma outra novidade: células especializadas, chamadas nervos, por onde passam impulsos elétricos que estimulam a contração dos músculos.

Trago os cnidários não para afirmar a existência de um parentesco evolutivo entre as suas células musculares e a estrutura celular cardíaca humana. Os próprios cientistas engajados em investigar as origens e linhas evolutivas das células

\footnotetext{
${ }^{8}$ A William Harvey é atribuída a descoberta da circulação sanguínea e a consequente centralidade do coração na anatomia dos animais. Harvey formulou a circulação sanguínea seguindo a teoria desenvolvida por Cesalpino, médico e filósofo do século XVI, que foi o primeiro a afirmar o movimento do sangue em direção centrípeta num circuito fechado, referindose pela primeira vez ao termo circulação, porém no sentido de circulação química, e não física (mecânica). Desde a emergência da concepção da circulação sanguínea, atribuída à William Harvey (1578-1657), o caráter receptivo do coração foi obscurecido por seu argumento a respeito da atuação do sangue para a circulação, impulsionado pelo coração, visto, portanto, como ativo, mas não no sentido que quer atribuir Pollock: ativo em sua passividade, cujo impulso seria possibilitado pela abertura de espaço.
} 
musculares e proteínas especializadas na contração ressaltam a dificuldade de afirmar esse vínculo, dado que o processo evolutivo é bastante complexo e a semelhança estrutural não é uma relação forte o bastante para afirmar a origem comum. São complexas as linhas que nos trazem até os nossos atuais corações, músculos pulsantes pelos quais percorrem correntes elétricas capazes de gerar impulsos que propagam o movimento do órgão e a circulação do sangue pelo corpo. Não se trata de afirmar a pulsatilidade como um dado, e muito menos sugerir que a interrupção do fluxo pode representar uma transformação na espécie. Inspirada nos Cnidários, o ponto é destacar a relação entre vida e movimento nas ciências da vida, assim como problematizar a excepcionalidade humana enquanto espécie fechada, reconhecendo possíveis contribuições de outras espécies.

Segundo Apolo, pesquisador da bioengenharia a quem conheci no âmbito da pesquisa de doutorado, fazer as coisas movimentarem é relativamente complicado, tanto que os organismos humanos possuem dispositivos específicos para essa tarefa - em referência aos neurônios motores, que tiveram que se especializar, porque criar movimento não é simplesmente trocar informação, mas transformá-la em movimento. Em sua leitura de trechos da tese ${ }^{9}$, Apolo relacionou o movimento ao calor, sugerindo que: "O cérebro é frio, não pulsa, não se movimenta, não poderia nele encerrar as emoções humanas, que são tão ricas em aquecer sensações no corpo e fora dele, que digam os amantes”. Se por um lado cérebro e coração se assemelham por serem ambos órgãos elétricos, por outro lado a geração de movimento, para além de troca de informação química e elétrica, é uma especificidade do coração. Não pretendo com essa descrição reforçar a contraposição entre cérebro e coração, mas aproveitar o insight do Apolo sobre os sentidos (inclusive poéticos) do movimento. Essas aproximações e distanciamentos entre cérebro e coração sugerem certa transitividade de gêneros presente na manutenção e problematização da divisão binária entre eles, o que se espelha nos binarismos razão e sentimento, informação e ação. Retornarei à transitividade de gênero do coração ao final da seção sobre os sistemas hidráulicos.

Apesar de destacar o caráter elétrico do coração e sua relação com o movimento, é preciso considerar que as características elétricas, mecânicas e hidráulicas do órgão estão relacionadas e entrelaçadas na fisiologia "nativa”. É bem verdade que os saberes biomédicos que operam nessa chave de ordenação dos sistemas os isolam e procuram apartá-los na tentativa de controlar a complexidade do corpo, tornando possível sua manipulação. Não só há uma dependência entre os sistemas, no entanto, como é preciso considerar que a atuação do sistema circulatório é condicionada no/pelo ambiente. O impulso gerado no coração, elétrico e mecânico, se dissipa para o sangue, que percorre os vasos sanguíneos, até a fronteira da pele, constituindo um sistema semiaberto (ou semifechado). Caracterizados como um sistema composto por um conjunto de subsistemas encerrados em uma fronteira porosa e relacional, o corpo e a fisiologia nativa estão sujeitos às condições ambientais. Uma evidência é a convenção relativa à pressão sanguínea considerada padrão, que é uma medida que varia em relação à pressão atmosférica.

As patologias são também evidências do modo como o coração se constitui no e pelo ambiente. Se um órgão tiver demandas maiores do que aquelas para as quais as suas estruturas nativas foram moldadas, ele responderá, adequando-se às condições. Se a necessidade e disponibilidade de sangue for maior do que a que

9 Meses antes de entregar a tese, eu submeti capítulos preliminares a alguns interlocutores. Apolo leu e devolveu o arquivo de PDF comentado. O trecho aqui reproduzido é parte de um comentário feito por ele, que se assemelhava a uma poesia. 
o coração pode bombear, ele se tornará maior ("inchado") em resposta ao processo de adequação à demanda. Ao trabalhar acima da sua capacidade (nativa), o que possivelmente alterará também seu ritmo, o coração terá suas estruturas modificadas.

Da perspectiva do órgão, portanto, os sistemas que compõem o organismo, ou seja, os outros órgãos, a circulação sanguínea, o sangue, assim como a atmosfera e o espaço/tempo para além da pele são os ambientes com os quais ele está em relação. O espaço, o tempo e suas variações dentro do sistema (parcialmente) limitado pela pele, portanto, estão sempre em relação às medidas e padrões para além da pele.

De acordo com compreensões que informam a biomedicina a respeito da fisiologia, humanos podem ter distintos "ritmo sinusais"10, ou seja, o ritmo fisiológico do órgão, ou o ritmo nativo ${ }^{11}$ mais adaptado às próprias necessidades de cada organismo. Mas há uma faixa de batimentos por minuto (bpm) considerada apropriada para a manutenção do organismo, que varia entre 50 e $100 \mathrm{bpm}$.

A instituição de uma taxa de normalidade é uma convenção determinada a partir de dados estatísticos populacionais ${ }^{12}$. Uma frequência cardíaca alta, ou seja, acima dessa faixa, indica que o coração está fazendo mais esforço para levar sangue para o corpo. O ideal é que a distribuição do sangue seja realizada com a frequência cardíaca mais baixa, sem, no entanto, comprometer a distribuição regular e igualitária, que permita que o sangue atinja todas as partes e órgãos.

Atentar-se para o sangue implica considerar os ritmos, assim como a relação com a velocidade. Situações de velocidade muito alta ou muito lenta - não necessariamente provocada pelo aumento da frequência cardíaca, mas também pela modificação na conformação dos tubos por onde passa o sangue, como em situações de estreitamento dos vasos, por exemplo - podem causar alterações no fluxo do sangue, que são caracterizados de duas formas: laminar ou turbulento ${ }^{13}$. A velocidade é, portanto, uma razão entre o fluxo e a área.

De acordo com as concepções biomédicas que informam a produção de dispositivos mecânicos, o sangue é um fluído impulsionado para oxigenar as células do corpo, órgãos e tecidos. Há uma funcionalidade tautológica do sangue, de modo que ele circula para oxigenar, e oxigena porque circula, o que se dá sempre

\footnotetext{
${ }^{10} \mathrm{O}$ ritmo sinusal é descrito como o ritmo normal. Nó sinusal é o nome de uma estrutura, um emaranhado de células cardíacas especializadas, também conhecido como “marca-passo cardíaco". Responsável por emitir estímulos para que o coração pulse, o nó sinusal (ou sinoatrial) é o local da gênese da atividade elétrica cardíaca. Assim, o nó sinusal envia os sinais elétricos que se estendem para a musculatura ventricular, formando uma extensa rede de condução intraventricular - as fibras de Purkinje. Tal transmissão é possível graças aos receptores presentes no sarcolema - que é uma camada de tecido conjuntivo que envolve a fibra muscular - que interagem com as moléculas que atuam na passagem do impulso nervoso dos neurônios para as células musculares (a acetilcolina). Trata-se de um neurotransmissor do sistema nervoso parassimpático que inerva o coração. A interação entre o neurotransmissor e o receptor ativa um canal de potássio que provoca o aumento no potencial de repouso (hiperpolarização), bem como um encurtamento dos potenciais de ação atrial e nodais, favorecendo e acelerando a repolarização (AIRES, 2008).

${ }^{11}$ Utilizo o termo nativo, tal qual é possível encontrar algumas vezes na literatura biomédica, para me referir ao órgão, corpo, fisiologia e suas funções originais. Escapar do termo "natural" é conveniente porque é preciso qualificar a naturalidade do que é entendido como orgânico ou fisiológico, e questioná-los enquanto termos opostos à produção supostamente artificial. $\mathrm{O}$ esforço ao longo de todo o artigo é justamente explicitar a inexistência de órgãos ou funções naturais, que se sustentam fora de práticas sociomateriais, dos desenvolvimentos biomédicos e ou resultantes de práticas imanentes da bioengenharia.

${ }^{12}$ A instituição de um parâmetro remete a uma certa normalidade fisiológica, um cálculo produzido a partir da média populacional. De acordo com Georges Canguilhem (1990), a partir do século XIX a definição das fronteiras entre o normal e o patológico é orientada pela qualificação do patológico como uma variação quantitativa do normal, ou seja, semanticamente, o patológico é designado a partir do normal, não tanto como a ou dis mas como hiper ou hipo. Interessa destacar em seu argumento que toda instituição de uma proposição de normalidade é, necessariamente, uma intervenção valorativa e, portanto, normativa.

${ }^{13}$ O fluxo laminar está associado aos vasos, que são cilíndricos. Caracteriza-se como uma série de lâminas fixas, com velocidades diversas, que tendem a diminuir sua velocidade ao se aproximarem da parede. O fluxo turbulento é associado à perda da qualidade linear das lâminas, produzindo alterações de velocidade e direção. É característico de certas estruturas do órgão, como o ventrículo, as câmaras cardíacas, mas também em ramificações onde o sangue obrigatoriamente sofre mudanças em sua direção. O fluxo turbulento também pode ser resultante de condições patológicas, como na aterosclerose (AIRES, 2008).
} 
em relação ao espaço e ao tempo. Abordar o movimento do coração no âmbito da produção e utilização de órgão artificiais nos leva a explorar as transformações produzidas pelo arranjo entre o órgão nativo e o dispositivo mecânico, iluminando as convenções sobre fluxo, velocidade e ritmo que marcam a circulação sanguínea, bem como as transformações em tais padrões.

E por quê afinal interessa abordar o movimento produzido pelo coração, retornando à criação do movimento pelos Cnidários? Porque considerar o que carrega o sangue, do ponto de vista do coração e dos desafios postos às tentativas de sua substituição ou solução de suas possíveis falhas remete à sua movimentação, à produção da circulação, à compreensão de seus fluxos, velocidades e ritmos que podem ser alterados com o uso de tecnologias cardíacas.

O trabalho do órgão nativo e seu movimento, que apresenta um caráter flutuante cíclico, é representado graficamente nas figuras 1 e 2. Na primeira vemos a curva produzida pela variação de pressão no ventrículo esquerdo nos momentos de enchimento e relaxamento da câmara cardíaca. Na figura seguinte é possível observar a variação de pressão relacionada à abertura ou fechamento da válvula aórtica da qual decorre a entrada de sangue, o enchimento ou relaxamento isovolumétrico. Não são representações facilmente compreensíveis, sobretudo para pessoas pouco afeitas a demonstrações gráficas. O propósito, no entanto, é justamente demonstrar a complexidade das representações, assim como os fatores considerados na variação de pressão e fluxo sanguíneo. A frequência cardíaca é calculada/modulada a partir das contrações do órgão por minuto. Ela indica a variação rítmica do órgão num dado espaço de tempo, constituindo um ciclo cardíaco.

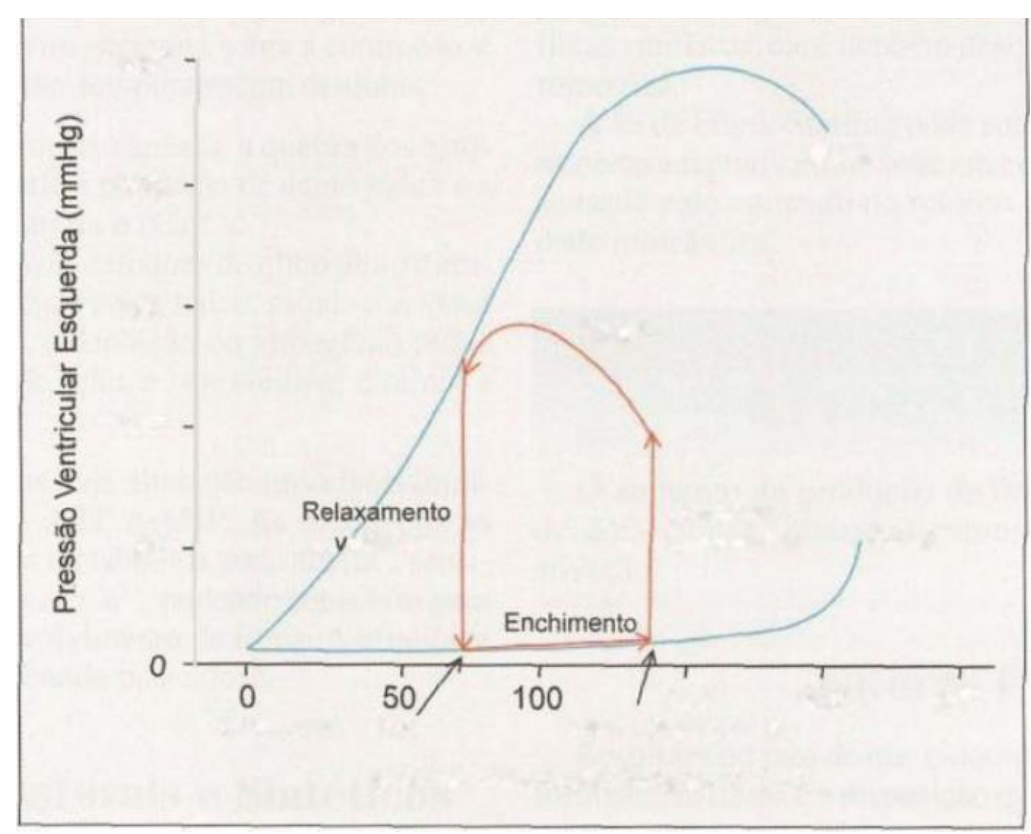

Figura 1 - Demonstração gráfica das quatro fases de variações da pressão e do volume intraventricular esquerdo durante um ciclo cardíaco. Fonte: AIRES, 2008 


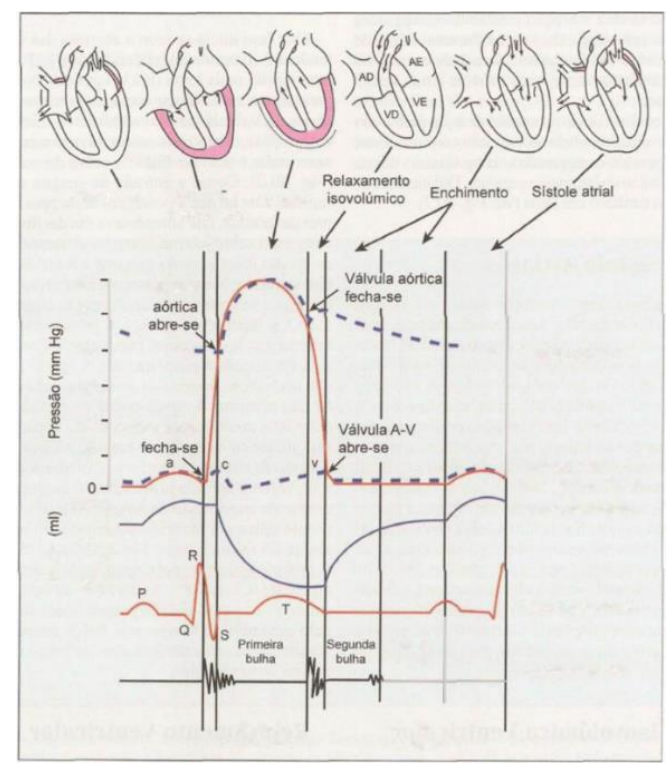

Figura 2 - Ciclo cardíaco. Relação temporal entre as pressões atrial, ventricular e aórtica, o volume ventricular, o eletrocardiograma e o fonocardiograma. Fonte: AIRES, 2008

\section{Os caminhos, constrangimentos e fluxos do sangue}

Apesar de disciplinado pelas paredes dos quilômetros de vasos sanguíneos nos quais circula e que o contém, o sangue por vezes escapa ao confinamento, produzindo descontroles e novas relações. O sistema circulatório é constituído por porções arterial, capilar, venosa e linfática, compondo uma rede de tubos cuja extensão pode alcançar em média 50 mil quilômetros, na concepção biomédica sobre a fisiologia humana.

Nesse arranjo, a pele é tomada como fronteira que delineia o corpo, cujas partes são oxigenadas e se comunicam pelo sangue, contido pelas paredes dos vasos sanguíneos. A pele apresenta-se como demarcadora de um sistema que deve ser tomado como semiaberto (ou semifechado), uma vez que as relações se dão também para além dela. Se a delimitação é fictícia, em certo sentido, porque há sempre certa "porosidade", ela é, ao mesmo tempo, real e produtiva - o que é evidenciado nas situações em que a contenção do sistema circulatório é extrapolada, como nos casos de vazamentos ou derramamento de sangue, como veremos a seguir.

O pesquisador da bioengenharia, Apolo, definiu o sistema circulatório como perfeitamente fechado (hermético, em referência às leis herméticas, propostas pelo filósofo antigo egípcio Hermes Trismegisto), no sentido de que não há vazamentos (ou não deve haver). Segundo ele, o sangue é contido nos vasos sanguíneos por conta da viscosidade do líquido e da pressão, que é equivalente à pressão atmosférica, ocorrendo um equilíbrio de pressão. Se a pressão interna for maior ou menor do que a atmosférica, o sangue pode vazar. Além disso, se o líquido sofrer alterações em sua viscosidade (pelo efeito do uso de anticoagulantes, por exemplo), pode haver vazamento. Os vasos, a viscosidade do sangue e a pressão se relacionam em condições específicas, adaptados uns aos outros.

Houve uma situação na pesquisa etnográfica em que, ao preparar o campo para um procedimento in vivo - ou seja, transformar o corpo de um porco em 
campo, o que significa naturalizá-lo, isolar o órgão a ser operado, cobrindo o restante do animal e abrindo uma nova fronteira 14 - o cirurgião auxiliar que abria as costelas para acessar o órgão deixou escapar o bisturi, cortando um vaso, o que fez jorrar sangue para o alto intensamente. Nessa situação, o sangue não se comportou exatamente como um ator. Ela pode ser tomada como um imponderável que adicionou dramaticidade à cena cirúrgica, mas sem grandes consequências para o procedimento. Apesar de inesperada, o sangue não atuou de maneira imprevisível. Além disso, a participação do sangue impulsionado para cima explicita, a um só tempo, a existência da pressão sanguínea e a contenção do sangue pelos vasos.

Para além de vasos rompidos acidentalmente em procedimentos cirúrgicos, há um desdobramento do uso de corações artificiais que atualmente é reconhecida como uma das principais causas de morte de pessoas cujos órgãos são acoplados a esses dispositivos, e que está diretamente associada à atuação do sangue e seu entrelaçamento a outros actantes. Trata-se da ocorrência de hemorragias no interior do corpo, ou seja, o vazamento de sangue decorrente da mudança de sua viscosidade por conta do uso de anticoagulantes.

Nona, um paciente que foi interlocutor da pesquisa, e que viveu mais de dois anos e meio com um Dispositivo de Assistência Ventricular (DAV), um modelo específico dentro da classe de dispositivos mecânicos conhecidos como corações artificiais, assumiu posição de prioridade na fila de transplantes de órgãos, em março de 2017, quando apresentou sangramentos internos (no estômago). A dificuldade em controlar a hemorragia foi decisiva para a equipe responsável pelo caso decidir pleitear a posição de prioridade.

Os transplantes de coração instituem um corpo imunológico, cuja identidade é ameaçada pela presença de intrusos, o que requer a "intrusão" de imunossupressores - alterando e enfraquecendo a identidade do sistema, tornando-o vulnerável. Em contraposição, o corpo performado com o acoplamento aos corações artificiais, que proponho chamar de corpo biônico ${ }^{15}$, prevê a participação de anticoagulantes para desfazer a possibilidade de intrusão de trombos, que representam falhas na incorporação do dispositivo. ${ }^{16}$ São ambos corpos performados e que implicam intrusões, mas de ordens diversas. Além disso, deve-se considerar que os diferentes dilemas impostos ao corpo imunológico e ao corpo biônico promovem distintas ontologias ao sangue.

O corpo biônico emergido na relação com os dispositivos mecânicos prevê a participação imperativa de anticoagulantes para evitar a formação de coágulos, que podem obstruir artérias ou veias e provocar um ataque cardíaco ou um acidente vascular cerebral (AVC). Mas um dos desdobramentos possíveis associado ao uso de anticoagulantes é a ocorrência de sangramentos.

A coagulação, ou seja, uma complexa reação química que transforma o líquido em gel sólido ocasionando a formação de trombos, é um mecanismo inteligente da circulação sanguínea nativa para conter uma hemorragia. No caso da associação da fisiologia nativa ao coração artificial, a coagulação pode ser um efeito indesejado da circulação mecânica, que pode produzir áreas de estagnação

14 Para uma compreensão aprofundada da formação do campo ver Marini, 2019.

${ }_{15}$ Para uma discussão mais aprofundada sobre as distinções entre corpo biônico e corpo imunológico ver Marini, 2018.

${ }^{16}$ O que se passa é a socialização dos corações artificiais, aos moldes do que é proposto por Phillipe Pignarre (1999) em relação aos medicamentos. Para ele, socialização remete à construção de um conjunto complexo de mediações entre humanos e não-humanos para que um encontro potencialmente disruptivo seja menos conflituoso. Essa foi uma lembrança de um dos pareceres que o artigo recebeu, no qual a/o autor/a destaca que Pignarre sugere que os experimentos prévios à comercialização dos medicamentos são uma espécie de domesticação dos fármacos, implicada justamente por seu processo de socialização durante os experimentos. 
do sangue, ou mesmo atuar como um "triturador" de células, ampliando as chances de produção de coágulos. Grande parte dos esforços de aprimoramento das hélices da bomba diz respeito ao desenvolvimento do melhor desenho, capaz de reduzir danos às células e o menor índice de formação de coágulos, o que é cercado e avaliado em testes de bancada, ou seja, os testes in vitro aos quais são primeiramente submetidos os corações artificiais.

Nesses testes, o sangue humano é traduzido em termos de sua viscosidade, ou seja, é substituído por um preparado de álcool e glicerina em concentrações que mimetizam a viscosidade do sangue para que se possa avaliar o desempenho das bombas em situações mais próximas possíveis àquelas a que estarão expostas quando implantados junto aos órgãos de pacientes humanos. Nesse caso suas células, ou seja, a miríade de seres que compõe o sangue vivo não importa. Trata-se de um momento em que o que está em questão é a performance hidrodinâmica (ou melhor, hemodinâmica, pois embora não seja sangue nativo, sua viscosidade, que é o ponto em questão, é mimetizada).

Há testes em que a taxa de hemólise, o que é denominado determinação do índice normalizado de hemólise (INH), que é a medida de destruição das células em decorrência da interação inadequada entre o dispositivo e o organismo, é calculada. Nesses casos, assim como nos testes de biocompatibilidade dos materiais, nos quais também está em questão a condição das células do sangue, ao invés do composto de glicerina utiliza-se sangue de animais não-humanos - que é naturalizado para performar o sangue humano. ${ }^{17}$ Se nos estudos de parentesco a potência do sangue pode ser expressa, em partes, por sua competência em produzir parentes, nos testes laboratoriais, experimentais e clínicos para a produção de corações artificiais, guardadas as diferenças, o sangue e suas traduções também produzem relações. Os porcos, seu sangue e o preparado que mimetiza o sangue estão todos associados e intimamente relacionados, caracterizando-se como seres-em-relação (MARRAS, 2014). A atuação de todos esses seres nas cirurgias experimentais e testes laboratoriais caracteriza-os não só como "substitutos de humanos" ou como modelo animal (ou organismo-modelo), mas coloca humanos e animais em relação e participação material/semiótica (HARAWAY, 2003).

Não sei ao certo porque não é usado sangue humano nesses procedimentos, mas imagino que o fato de se tratar de um recurso escasso e valioso (moral e economicamente) possa ser uma das razões. Além disso, é muito recorrente que em testes de bancada sejam produzidos artefatos simuladores do corpo humano e suas partes. Nas práticas laboratoriais e clínicas, portanto, o sangue humano pode aparecer traduzido por sua viscosidade ou por seu parentesco (fisiológico) com outros mamíferos, como suínos e bovinos.

Tubos que somam quilômetros de extensão, pelos quais navegam um fluido viscoso, que circula em determinadas velocidades e fluxos, vasos que podem sofrer estreitamentos, ou rompimentos, produzindo vazamentos - que também podem ser motivados por variações na viscosidade do fluido - são todos fatores que falam sobre os caminhos percorridos pelo sangue. Simultaneamente, os desafios em torno da produção de dispositivos auxiliares à circulação sanguínea são de várias ordens, relacionando-se sobretudo à problemática da variação de pressão sanguínea, à resistência dos materiais dado o contínuo bombeamento, à ocorrência de áreas de estagnação e aumento do risco de aglutinação de células - dinâmicas relacionadas à circulação dos fluídos, que se desdobram na problemática da preservação das células.

${ }_{17}$ Para uma explanação a respeito do que processo de naturalização de animais não-humanos que atuam como substitutos de animais humanos ver Marini, 2018. 
Em síntese, a problemática da circulação pode ser sistematizada em torno de dois aspectos associados ao órgão: o elétrico e o hidráulico. $\mathrm{O}$ aspecto elétrico pode ser mapeado pelos sinais geradores de impulsos responsáveis pela contração do músculo, ${ }^{18}$ que remete à transformação de informação em movimento, o que foi explorado em diálogo com os cnidários, e suas inovações relativas aos músculos e produção de movimento. O caráter hidráulico relaciona-se aos maiores desafios associados à produção de dispositivos de assistência circulatória, que dizem respeito às dificuldades em instituir mecanicamente a perfusão celular, ou seja, distribuir o sangue pelo corpo de maneira eficaz e adequada, o que exige força, potência e delicadeza, para que na interação com o organismo o coração artificial não danifique as células do sangue. Partamos para uma reflexão sobre o caráter hidráulico e as metáforas produzidas a partir dele.

\section{Uma pequena arqueologia dos sistemas hidráulicos e suas filosofias}

As soluções propostas para a circulação sanguínea auxiliar têm como fundamento a natureza mecânica e hidráulica do órgão nativo, do modo como é encontrada em formulações biomédicas que informam as práticas da bioengenharia. Com isso quero dizer que o órgão nativo, que é também um produto de práticas laboratoriais, clínicas e do conhecimento biomédico, é o ponto de partida para a produção de tecnologias, soluções e enfrentamento das limitações técnicas.

Para Ingold (2011), a ideia de humano "anatomicamente moderno" é uma ficção analítica. Trata-se, no entanto, de uma ficção operante, na medida em que, no caso do coração nativo, ao tentar compreender seu funcionamento para produzir tecnologias auxiliares ou substitutivas, os pesquisadores apoiam-se em uma ficção que serve de "molde" para a produção de dispositivos mecânicos. O que se passa é que não há natureza fora de laboratório, anterior à produção de conhecimento (LATOUR, 1997). Ao performar na clínica ou no laboratório, o coração nativo já não é o coração "natural". Além disso, é preciso destacar que, apesar da ideia de coração e do seu funcionamento normal/ideal serem frutos de análise, observação e mensuração de órgãos diversos, a produção de um modelo geral, universal, não abarca a diversidade de corações nativos existentes e enredados em seus próprios sistemas - por isso a possibilidade de imponderáveis e a emergência de novas relações na interação com os corações artificiais, também universalizantes. Grande parte dos desafios associados à produção de dispositivos de assistência circulatória remete à construção de um dispositivo cujo funcionamento possibilite uma amplitude de operações que mimetizem as imprevisíveis interações constitutivas de corações nativos.

Olhar para a natureza hidráulica nos leva ao coração como um ponto de passagem essencial para a distribuição democrática do sangue, estabelecendo uma comunicação e unidade ao organismo e seu entorno.

Os sistemas hidráulicos são recursos conhecidos desde a antiguidade, dada a importância da água para a agricultura e abastecimento hídrico das cidades e seus sistemas de canais, aquedutos, bombeamentos e elevações de água na Mesopotâmia, no Egito e em Roma, bem como na Índia e na China. Se atualmente eles são tidos como old fashioned diante de novos imaginários (POLLOCK, 2015), é preciso considerar a profusão de concepções produzidas pelos sistemas hidráulicos

${ }^{18} \mathrm{O}$ aspecto elétrico desempenha um papel fundamental na forma como o movimento do coração é mapeado, pois são os impulsos elétricos que tornam possível o reconhecimento das inscrições no eletrocardiograma (ECG). 
na Antiguidade e na Modernidade, quando representaram inovações associadas à compressão de fluidos.

Os desenvolvimentos modernos da hidráulica são fundamentados no princípio de Pascal, que estabelece que a alteração de pressão produzida em um fluido em equilíbrio transmite-se integralmente a todos os pontos do fluido e às paredes do seu recipiente. É curioso notar que o físico e matemático francês Blaise Pascal (1623 - 1662), além de ter fundamentado a lógica dos sistemas hidráulicos, é autor da célebre frase "o coração tem razões que a própria razão desconhece".

Assim como Pascal, René Descartes (1596-1650), seu contemporâneo, conhecido como o fundador da filosofia e da matemática modernas, também tratou de sistemas hidráulicos. Descartes propôs que o sistema nervoso funcionava como um sistema hidráulico, composto por tubos que transmitiam impulsos similares à pressão da água. Tal concepção se encontrará refletida no modelo hidráulico da mente instituído por Freud no século XIX - de certa forma sobrepujado pelo paradigma computacional da mente, embora ainda produza seus rendimentos. Para Freud a mente era formada por estruturas que operavam de acordo com o modelo de vasos comunicantes. As metáforas hidráulicas sustentavam suas ideias sobre as pressões mentais que se acumulavam, bem como a ideia de energia e pressão, associadas à ideia de uma necessidade de válvulas de escape. Em suma, o modelo hidráulico ${ }^{19}$, assim como as máquinas à vapor vitorianas, agitavam a construção do inconsciente e sua economia libidinal de desejo e repressão (DAUGMAN, 2001).

Pollock manifesta sua percepção de que os sistemas hidráulicos podem soar estranhamente antiquados no atual momento cibernético, e parecem estar distantes das questões quentes tanto para feministas quanto para cientistas. Há um aspecto que pode ser destacado, no entanto, que remete a certa transitividade de gênero associada ao coração. Para além do aspecto antiquado, o caráter hidráulico do coração combina, para Pollock, aspectos masculinos e femininos, ativo e passivo. Por um lado, o coração é um órgão muscular, que opera de acordo com um modelo fálico (TURNER, 2003 apud POLLOCK, 2015), ativo, que bombeia sangue para todo o corpo; por outro lado caracteriza-se por sua receptividade e passividade, que permite que ele seja um órgão que não apenas distribui o fluido, como o pênis, mas também o receba, permitindo que a circulação ocorra. Sua elaboração remete, como sugerido anteriormente, ao caráter receptivo inexistente na compreensão da circulação sanguínea desde William Harvey, cujo argumento ressalta a ação do coração como impulsão.

Podemos considerar que o coração é associado à feminilidade, sobretudo em contraposição ao cérebro, uma vez que a ele é atribuído certo sentimentalismo, romantismo e beleza. No imaginário social (co)produzido pelos saberes biomédicos, parece ter-se instituído concepções dicotômicas em relação ao cérebro e coração, reservando ao primeiro um caráter mais masculino, racional, objetivo, enquanto o coração é associado à subjetividade e feminilidade. Paradoxalmente (ou não), no entanto, o coração é também um órgão tomado como másculo e robusto, sobretudo nas concepções biomédicas e da bioengenharia, uma vez que é descrito como uma bomba potente, como um dos órgãos mais "fortes" do corpo, dado que bombeia litros de sangue por minuto ininterruptamente. Sua resistência e força

\footnotetext{
19 O modelo hidráulico remete aos conceitos de psique do pensamento pré-Socrático. A escola hipócrita de medicina defendia um modelo inicial da mente, segundo Daugman (2001), relacionado à teoria dos quatro humores corporais: sangue, fleuma, bílis amarela e bílis negra, que em desequilíbrio poderia decorrer em disposições mentais/emocionais - respectivamente sanguíneo, fleumático, colérico e melancólico. Tal teoria desencadeou, no século II, a teoria dos espíritos vitais de Galeno.
} 
incansáveis são, inclusive, barreiras ao desenvolvimento de dispositivos artificiais, uma vez que o bombeamento contínuo implica desgaste de materiais a longo prazo - preocupação que surge no desenvolvimento de dispositivos projetados para serem usados por períodos mais prolongados, como na terapia de destino, em que os dispositivos são implantados como alternativa ao transplante de órgãos.

\section{Sistemas hidráulicos como metáforas de pressão e mecanismos de escape}

Gostaria agora de recuperar o modelo hidráulico da mente para elaborar uma linha de fuga que possivelmente apenas a minha trajetória errante de pesquisa pode colocar em relação. Trata-se do modo como as formulações sobre as "pressões psíquicas" e necessidades de escape se desdobram na problemática dos transtornos alimentares, tema que explorei na pesquisa de mestrado. A associação entre os escapes das pressões psíquicas aos transtornos alimentares e outros quadros a eles relacionados foi formulada pelo psicanalista francês Eric Bidaud $(2010)^{20}$.

Bidaud inicia sua reflexão recuperando duas orientações teóricas para pensar o que chama de "sangramento provocado" no campo da psicanálise: a primeira associada a uma lógica de "econômica de descarga", e a segunda que trata de uma associação recíproca vampiresca entre mãe e filha.

Na leitura do autor, na primeira abordagem a automutilação da qual decorre o sangramento provocado estaria relacionada à um alívio tensional, um alívio de um estado de tensão interna, que não se dá pelo processo de incorporação - ou seja, de conhecimento ou manifestação de um sintoma que habita o corpo - mas sim pelo "esvaziamento, que desempenha uma espécie de figuração corporal (à falta de representação possível) do fantasma do se esvaziar da influência do outro" (CORCOS apud BIDAUD, 2010: 27).

Na segunda perspectiva o sintoma é pensado como uma espécie de reencenação, releitura ou nova roupagem de relações patológicas com a figura materna, descritas como "uma ligação mortífera sob o signo de uma associação recíproca mãe-filha, de um novo tipo de 'vampirismo'. 'Um corpo para duas. Um sangue para duas. Um sangue que se torna o objeto de um autovampirismo"' (SCHAEFFER apud BIDAUD, 2010: 27).

Uma questão que me ocorre, uma linha de fuga crítica que se coloca à proposição é: e se ao invés de ser pensada como vampiresca essa relação fosse entendida como da ordem da extrapolação de fronteiras do corpo delimitada pela pele como um fim, como nos provoca Donna Haraway (2009)? É certo que a relação que é elaborada como patológica no discurso psicanalítico está relacionada a padrões e situações de sofrimento. Mas e se a explicação para os sintomas desenvolvidos fosse buscada em outro lugar, que não a relação com a figura materna?

\footnotetext{
${ }^{20}$ Refiro-me ao artigo "Reflexões sobre a clínica dos sangramentos provocados", publicado em francês, mas também sua tradução para o português no livro "Psicanálise dos Transtornos Alimentares”, organizado por duas psicanalistas brasileiras especializadas em Anorexia e Bulimia Nervosas, Ana Paula Gonzaga e Cybelle Weinberg. O livro é uma coletânea que contou com artigos e análises de outras psicanalistas brasileiras, também especializadas nesses transtornos ou sintomas, para falar com a psicanálise e seu modo de elaboração dos quadros. O artigo abre a coletânea, buscando revisar teorias sobre "práticas de sangramento provocado" - sintoma que do ponto de vista psicanalítico estaria relacionado aos transtornos alimentares, segundo a lógica dessas especialistas no assunto, o que se evidencia pela sua presença no livro. Para a compreensão das especificidades e o modo distinto como a psicanálise pensa os sintomas em contraposição/relação à biomedicina, e para a investigação mais ampla a respeito da prática psicanalítica especializada em transtornos alimentares ver Marini, 2016.
} 
E se tal relação fosse elaborada na chave de uma solidariedade? Essas são questões retóricas, para nos lembrar que boa parte das explicações psicanalíticas (sobretudo as originárias) foram elaboradas por homens.

As principais elaborações psicanalíticas em torno dos transtornos alimentares encontradas no livro supracitado questionam, em linhas gerais, a possibilidade de instituição de pensamento simbólico mais elaborado, ou seja, a capacidade de simbolizar, de elaborar os conflitos e as relações, de modo que o que as pesquisas contidas no livro iluminam diz respeito à incapacidade de se expressar de maneira menos concreta, o que é caracterizado como "sintoma do agir". Na leitura das psicanalistas, a precariedade do pensamento simbólico está relacionada ao surgimento de falhas primárias que ocorrem em estágios muito precoces do desenvolvimento. Em linhas gerais, há um momento (lógico) de constituição pré-edípica, na qual a triangulação da resolução do complexo de Édipo deve se efetuar, de modo que a "lei paterna" se faça presente para a instituição de um "corte", necessário para que a filha desenvolva um psiquismo independente do psiquismo materno. Tais compreensões se referem ao mesmo tipo de associação recíproca descrita por Bidaud como vampirismo.

No caso da automutilação (sintoma também presente nos quadros de transtornos alimentares), soma-se às falhas de constituição do aparelho psíquico as problemáticas em torno do tabu da virgindade que, na teoria freudiana, está relacionado à proximidade entre o sangue da defloração e o sangue menstrual, que estão "na base de um temor essencial em relação às mulheres" (BIDAUD, 2010: 28), instituindo para os homens uma "alteridade inconciliável".

As inferências seguintes dizem respeito à sugestão de que o sangue deve permanecer oculto, de modo que as jovens que se automutilam, expondo sua carne e seu sangue, estão transgredindo esse disciplinamento. $O$ autossangramento, portanto, caracteriza-se como uma dupla transgressão: como eliminação daquilo que é involuntário, que é a presença do sangue regrado e controlado; como aniquilamento daquilo que deve permanecer oculto.

Nos sangramentos provocados o sangue é compreendido na chave da ligação com a figura materna. Trata-se de um corpo ligado ao corpo materno em sua união pelo sangue, considerando que o "corte" não se concretizou e que há uma associação recíproca:

\begin{abstract}
na maior parte dos casos do sangramento provocado (além da própria síndrome), não existe o sangramento de uma sem que seja evocado, mais ou menos diretamente, o sangramento da outra, mesmo que essa evocação seja mais frequentemente negada (a transfusão altruísta é, por exemplo, a forma de doar para a outra) e suponhamos que é na ligação com a outra mulher, com o corpo materno em sua união pelo sangue, que essas condutas podem fazer sentido. O sangue da jovem apela ao sangue da mãe. 'Portanto, o sangue tem, como primeira virtude de objetivo, o sexo materno como objeto a ser visto, em sua dupla potencialidade originária da ausência e da presença, da vida e da morte' (BONNET, p. 107). Assim, o sangue vertido pela filha se une imaginariamente ao sangue da outra. $O$ que permite identificar o fantasma de um reencontro imaginário entre filha e mãe, de uma união homossexual filha-mãe (que nos deu a base de nossa psicopatologia da anorexia). (BIDAUD, 2010: 32)
\end{abstract}

No caso do sangramento provocado, a aliança entre mãe e filha está vetorizada pelo sangue derramado, numa versão fantasmática de uma filiação pelo sangue, segundo Bidaud. Tal qual a recusa à comida, por exemplo, no caso da Anorexia Nervosa, tratam-se de manifestações de sofrimentos psíquicos, materializações precárias de angústias ligadas a momentos primitivos da constituição da psique, mecanismos que expressam uma cisão entre corpo e mente, relativos a falhas primárias que não possibilitaram uma diferenciação entre mãe e filhas, não havendo rupturas com a figura materna internalizada. 
Teorias originalmente escritas por homens, que elaboraram o tabu da menstruação como um temor essencial em relação às mulheres, e que formalizam o vínculo entre mães e filhas - tanto nos casos dos transtornos alimentares, como na síndrome de Lasthénie de Ferjol, recuperada por Bidaud no artigo, relacionada ao sangramento provocado - como uma simbiose vampiresca na qual as marcas no corpo funcionam como a "presença encarnada (no sentido mais próximo da etimologia do termo) do Outro materno" (BIDAUD, 2010: 34). Desse ponto de vista, trata-se da corporificação/incorporação do Outro - ou melhor, da outra, a própria mãe - o que é interpretado por Bidaud como o testemunho da falta de significado na relação com o Outro.

O que poderia ser pensado como um fenômeno de apropriação do próprio corpo, de reconhecimento das fronteiras entre o corpo e o mundo, é interpretado como a dificuldade de enfrentar significados. Nesse caso o agir é compreendido como um rompimento com a associação com o Outro e uma forma de inscrever uma ligação, por mais rudimentar que seja, entre o Um e o Outro. Cortar o próprio corpo e sangrar é lido como o testemunho do agir. Permanecer no agir é uma forma de se proteger do ato que significa relação, diferença, na compreensão dessa corrente psicanalítica. É a um só tempo uma tentativa de marcar, mas também diluir a divisão subjetiva entre o eu e o Outro, ou seja, um esforço de se proteger da relação e ao mesmo tempo da divisão.

Trago essa aproximação inusitada de campos de produção de conhecimento tão diversos buscando relacioná-los em duas frentes: a primeira relativa à problemática do sangue, suas potencialidades e vazamentos; e a segunda a respeito dos desenvolvimentos relativos aos sistemas hidráulicos. No caso da síndrome relacionada ao ato de provocar sangramento, o modelo hidráulico da mente remete à compreensão dos sintomas - nesse caso a automutilação - como expressão dos sofrimentos não elaborados, remetendo à nossa dificuldade de processar, elaborar, compreender e promover mudanças. A incapacidade de elaborar os conteúdos psíquicos, de simbolizar as relações, resulta em estratégias que se caracterizam como válvulas de escape, que podem passar pela tentativa de empurrar conteúdos para o inconsciente, projetar a culpa e a responsabilidade do sofrimento, de modo que a pressão e as válvulas de escape surgem como resposta a uma relação de projeção com o mundo/outro.

A partir de imagens e teorias fragmentadas é possível aproximar sintomas fisiológicos e psíquicos relativos à pressão no âmbito das teorias hidráulicas, sejam elas referentes à mecânica dos fluídos, ou ao modelo de compreensão da mente. Se por um lado há quem defenda que doenças psíquicas ou emocionais podem ganhar uma expressão somática, na própria carne, como o faz Bidaud, há quem argumente que as patologias cardíacas podem decorrer de questões emocionais (SILVA, 2016). Não é esse tipo de relação e paralelo que pretendo sustentar aqui, até porque refiro-me a sintomas e patologias diversas, cuja aproximação é complexa, mas sim produzir uma analogia entre a pressão sanguínea e a pressão psíquica. O ponto é oferecer análises e aproximações sobre a circulação sanguínea e a incapacidade de lidar psiquicamente com o mundo/outro, de modo que sintomas podem ser tomados como válvulas de escape, "vazamentos", o que pressupõe sistemas fechados hermeticamente, nos quais o sangue é fluido contido e disciplinado.

O "sangramento provocado" na automutilação, tal qual o vazamento inesperado na cena cirúrgica em que o bisturi rompe um vaso e faz jorrar sangue, e o sangramento involuntário em pacientes com corações artificiais, parecem nos fa- 
lar de vazamentos "antiprodutivos", no sentido sugerido por Gilles Deleuze e Felix Guattari ao tratarem do "Corpo sem órgãos" (2010, 2012). Antiprodutivo em relação contrastante à produção desejante do "Corpo sem órgãos", improdutivo para os órgãos organizados em sistemas. Deleuze e Guatarri evocam o "Corpo sem órgãos", proposto por Antoine Artaud, como um corpo pelo qual o desejo flui, sem limitar-se à organização, sem uma divisão teleológica pela qual aos órgãos e tecidos são atribuídas funções e funcionamentos normais ou patológicos. Diante disso, pode-se considerar que o sangue contido em vasos e veias revela uma ontologia que parece emergir como pura teleologia, materialização pura de funções e organização. Mas como pensar os diferentes transbordos e escapes, seja do procedimento in vivo descrito anteriormente, seja nas considerações acerca do sangue que se verte em práticas de automutilação e que são capturadas por um discurso generificado da psicanálise, que cristaliza posições materna e paterna como instauradoras de normas e significados, contra as quais insurge-se o Anti-Édipo? Que desejos são estes e como fluem nesses diferentes corpos, que desafiam a organização? Que corpos são estes que produzem des-orgão-nização?

Vasos rompidos acidentalmente, vazamentos provocados pelas mudanças na viscosidade do sangue, práticas de automutilação que resultam em sangramentos. São relações que remetem ao "Corpo sem órgãos”, “antiprodutivas”, sem função ou objetivo para a lógica teleológica do corpo predeterminado, previsível. Trata-se de situações desarranjadas, abertas aos fluxos e intensidades, incontidas, sem aprisionamento a um sistema organizado. As analogias aqui propostas entre sistemas hidráulicos, circulação de fluídos em sistemas fisiológicos e a metáfora hidráulica da mente apontam para a cisão moderna coração/mente; emocional/racional; feminino/masculino.

\section{Ontologias múltiplas, fluidas, úmidas}

Na tentativa de amarrar as temáticas diversas aqui recuperadas, recorro à elaboração de Annemarie Mol e John Law a respeito dos fluidos ou de uma espacialidade fluida como um acréscimo às teorias sociais que abordam fenômenos/espaços não definidos por fronteiras ou conectados em relações estáveis. A elaboração proposta em Regions, Network and Fluids: Anaemia and Social Topology é duplamente conveniente: primeiro porque fala de sangue e do modo como ele bagunça os valores espaciais da anatomia, mas também por propor outro tipo de distúrbio, referente à fluidez na teoria social, explorando as pressuposições tipológicas que enquadram a performance de similaridades e diferenças sociais, destacando a multiplicidade.

A imagem de fluidez para avançar frente à rigidez dos espaços e dos elementos nas redes parece profícua e, de certa forma, uma metáfora para pensar a fluidez do sangue e suas potencialidades no âmbito da produção de dispositivos de assistência circulatória. Concepção que pode encontrar reverberação na proposição de uma ontologia úmida (STEINBERG e PETERS, 2015, apud BOUCQUEY et al., 2016), que destaca a potencialidade para a reimaginação e revitalização de um mundo em movimento. Trata-se de uma perspectiva de enquadramento de um mundo de fluxos, liquidez e devir.

As abordagens teóricas aqui apresentadas têm em comum o interesse em produzir narrativas e entendimentos não-antropocêntricos, destacando a prática e a materialidade como centrais. Trazer as práticas para o primeiro plano, e não mais considerá-la como suporte dos objetos tem efeitos: a realidade se multiplica, como sugere Mol (2002). O reconhecimento de uma multiplicidade ontológica 
não tem interesse em questionar se as representações da realidade são precisas, mas compreender a maneira como os objetos são performados, de modo que não há realidade anterior ao seu ordenamento por meio das práticas. É a realidade que é múltipla, e não as perspectivas e pontos de vista sobre ela(s). Desse modo, não há mais um único objeto passivo, esperando para ser visto do ponto de vista da série aparentemente interminável de perspectivas.

Tal mudança carrega consigo o potencial de uma nova política ontológica. John Law (2011) propõe que no caso das ontologias múltiplas, o real (ou reais) são efeitos de encenações, performances ou conjuntos de relações contingentes e heterogêneos. O rendimento de tal proposição para as reflexões aqui apresentadas refere-se à não redução das diferenças, permitindo reconhecer as distintas ontologias do sangue.

Meu intuito ao recuperar uma ecologia de práticas científicas e médicas foi demonstrar como, em situações específicas, o sangue é traduzido como viscosidade, mas em outras práticas ele emerge como desafio hidrodinâmico em sua relação com o coração e sua circulação por quilômetros de vasos sanguíneos. O sangue também pode emergir como emaranhado de seres (vivos) que podem aglutinar-se. Em cada uma dessas situações o sangue faz coisas distintas, entrelaçandose a actantes também distintos, de modo que devemos olhar para as práticas laboratoriais e clínicas como produzindo sangues múltiplos (ou sangue múltiplo, no sentido que Mol dá ao termo "corpo múltiplo"). E essa não é apenas uma estratégia retórica de transformar a categoria em plural, mas reconhecer que, levando à sério a materialidade, não podemos descrevê-la como uma forma cultural, embora ela seja histórica e cultural.

Mais do que historicizar, localizar concepções tidas como culturais, é preciso desdobrar e problematizar a cultura como representação, a compreensão de substância como (apenas) metáfora. Como sugere Mol, a matéria nunca está sozinha. E a divisão não pode ser tomada como ponto de partida, muito menos como dada. Desse modo, uma nova abordagem materialista permite deslocar estruturas dualistas, permitindo a conceitualização da passagem dos fluxos da natureza e cultura, matéria e mente (BARAD, 2017). Levar à sério as abordagens não-antropocêntricas, voltadas para a prática e para a materialidade, conferindo ênfase ao multinaturalismo, à alteridade e à simetria implica enfraquecer a confiança em categorias de pensamento amplamente aceitas (HARRIS e ROBB, 2012).

Recebido em 7 de janeiro de 2020.

Aprovado em 8 de agosto de 2020.

\section{Referências}

AIRES, Margarida de Melo. Fisiologia. Rio de Janeiro: Guanabara Koogan, 2008.

BARAD, Karen. "Performatividade pós-humanista: para entender como a matéria chega à matéria”. Vazantes, 1 (1): 7-34, 2017.

BIDAUD, Eric. "Reflexões sobre a clínica dos sangramentos provocados”. In: GONZAGA, Ana Paula; WEINBERG, Cybelle (org.). Psicanálise de Transtornos Alimentares. São Paulo, Primavera Editorial, 2010. 
BOUCQUEY, Noëlle et al. The ontological politics of marine spatial planning: Assembling the ocean and shaping the capacities of 'community' and 'environment'. Geoforum, 75 (1): 1-11, 2016.

CANGUILHEM, Georges. O Normal e o Patológico. Rio de Janeiro: Forense Universitária, 1990.

COOLE, Diana; FROST, Samantha (orgs.). New Materialisms: Ontology, Agency, and Politics. Durhan: Duke University Press, 2010.

DAUGMAN, John. "Brain metaphor and brain theory". In: BECHTEL, W. et al. (eds.). Philosophy and the Neurosciences. Oxford: Blackwell, 2001.

DELEUZE, Gilles; GUATTARI, Félix. O anti-Édipo: capitalismo e esquizofrenia. São Paulo: Ed. 34, 2010.

DELEUZE, Gilles; GUATTARI, Félix. Mil platôs: capitalismo e esquizofrenia, Vol. 3. São Paulo: Editora 34, 2012.

HARRIS, Oliver J. T.; ROBB, John. Multiple Ontologies and the Problem of the Body in History. American Anthropologist, 114 (4): 668-679, 2012.

HARAWAY, Donna. "Manifesto Ciborgue: ciência, tecnologia e feminismo-socialista no final do século XX. In: SILVA, Tomaz Tadeu da (org.). Antropologia do Ciborgue - as vertigens do pós-humano. Belo Horizonte: Autêntica, 2000.

HARAWAY, Donna. The companion species manifesto: dogs, people, and significant otherness. Chicago: Prickly Paradigm Press, 2003.

HARAWAY, Donna. A partilha do sofrimento: Relações instrumentais entre animais de laboratório e sua gente". Horizontes Antropológicos, 17 (35): 27-64, 2011.

INGOLD, Tim. The perception of the environment: Essays in livelihood, dwelling and skill. Londres/Nova Yorque: Routledge, 2000.

INGOLD, Tim. Pare, olhe, escute! Visão, audição e movimento humano. Ponto Urbe, 2 (3.0) 2008.

INGOLD, Tim. Gente como a gente: $\mathrm{O}$ conceito de homem anatomicamente moderno" Ponto Urbe, 9, 2011.

LATOUR, Bruno; WOOLGAR, Steve. A vida de laboratório: a produção dos fatos científicos. Rio de Janeiro: Relume Dumará, 1997.

LATOUR, Bruno. “Technology is Society Made Durable”. In: LAW, J. (ed.). A Sociology of Monsters: Essays on Power, Technology and Domination. Sociological Review Monograph, 38: 103-132, 1991.

LATOUR, Bruno. Jamais fomos modernos: Ensaio de Antropologia Simétrica. Rio de Janeiro: Ed. 34, 1994.

LATOUR, Bruno. A Esperança de Pandora: Ensaios sobre a realidade dos estudos científicos. Bauru: EDUSC, 2001.

LATOUR, Bruno. Ciência em ação: como seguir cientistas e engenheiros sociedade afora. São Paulo: Editora UNESP, 2011.

LAW, John. What's wrong with a one-world world? Distinktion: Journal of Social Theory, 16 (1): 126-139, 2015. 
LECLERE, L. ; COPLEY R. R. ; MOMOSE, T. ; HOULISTON, E. Hydrozoan insights in animal development and evolution. Current Opinion in Genetics and Development, 39 (1): 157-167, 2016.

MARINI, Marisol. Corpos Biônicos e Órgãos Intercambiáveis: A produção de saberes e práticas sobre corações não-humanos. Tese (Doutorado em Antropologia Social) - Faculdade de Filosofia, Letras e Ciências Humanas, Universidade de São Paulo, São Paulo, 2018.

MARINI, Marisol. Por Uma Filosofia/antropologia Do Corpo: Materialismo Fenomenológico Ou Fenomenologia Materialista. Entrevista Com Jenny Slatman. Revista de Antropologia, 61 (1): 103-24, 2018.

MARINI, Marisol. Unproductive participation and protection against germs: Technical-ritualistic practices in heart surgery. Vibrant: Virtual Brazilian Anthropology, 16 (e16604), 2019.

MARRAS, Stelio. Virada animal, virada humana: outro pacto. Scientiae Studia, 12 (2): 215-260, 2014.

MARTIN, Emily. The end of the body? American Ethnologist, 19 (1) : 121-140, 1992.

MARTINS. Paula Mousinho. Entre visível e invisível, para além do entendimento: o tema da natureza no último Merleau-Ponty. Revista de Filosofia Aurora, 22 (31): 469-482, 2010.

MERLEAU-PONTY, Maurice. A natureza. Notas: curso do Collège de France. São Paulo: Martins Fontes, 2000.

MOL, Annemarie. The Body Multiple: Ontology in Medical Practice. Durham, NC: Duke University Press, 2002.

MOL, Annemarie; LAW, John. Regions, Networks and Fluids: Anemia and Social Topology. Social Studies of Science, 24 (4): 641-671, 1994.

MOL, Annemarie; LAW, John. Embodied action, enacted bodies: the example of hypoglycemia. Body \& Society, 10 (2-3): 43-62, 2004.

PIGNARRE, Phillipe. O Que é o Medicamento? Um objeto estranho entre ciência, mercado e sociedade. São Paulo: Editora 34, 1999.

POLLOCK, Anne. Heart Feminism. Catalyst: Feminism, Theory, Technoscience, $1(1), 2015$.

SAYES, Edwin. Actor-Network Theory and methodology: Just what does it mean to say that non-humans have agency? Social Studies of Science, 44 (1): 134- 149, 2014 .

SERRES, Michel. Variações sobre o corpo. Rio de Janeiro: Bertrand Brasil, 2004. SILVA, Marco Aurélio Dias de. Quem ama não adoece. Rio de Janeiro: BestSeller, 2016.

STEINMETZ, P.; KRAUS, J.; LARROUX, C. et al. Independent evolution of striated muscles in cnidarians and bilaterians. Nature, 487 (1): 231-234, 2012. 